\title{
A NEVELÉSTUDOMÁNY CSAK A TANÓRA TUDOMÁNYA?
}

\section{IS EDUCATION SCIENCE JUST THE SCIENCE OF THE CLASS?}

\author{
Trencsényi László ${ }^{1}$, Nagy Ádám², Flach Richárd ${ }^{3}$ \\ 1PhD, habil. címzetes egyetemi tanár, Eötvös Lóránd Tudományegyetem \\ trenyo@index.hu \\ ${ }^{2} \mathrm{PhD}$, habil. címzetes egyetemi docens, Kodolányi János Egyetem \\ ${ }^{3}$ PhD-ösztöndíjas, Pécsi Tudományegyetem
}

\begin{abstract}
ÖSSZEFOGLALÁS
A szerzők vitát kezdeményeznek a neveléstudomány korszerű értelmezéséről: szembeállítják a két létező nézetrendszert. Vitatják azt a neveléstudomány-felfogást, mely az iskolai folyamatokra szúkíti le kutatóinak érdeklődését. Egy másfajta neveléstudomány fontossága mellett érvelnek -a posztmodern-pluralista világ viszonyai között -, amely kísérletet tesz az iskolaközpontú neveléstudomány (oktatástudomány) történeti eredetének feltárására. Az abszolút monarchiák iskolarendszere kizárólagos legitimációra törekedett - s ezt a legitimációt rendelte meg a tudománytól.
\end{abstract}

\section{ABSTRACT}

The authors initiate a debate on a modern interpretation of educational science: they contrast the two existing view systems. They are debating the concept of education science, which reduces the interest of its researchers to school processes. They argue for the importance of another type of educational science - in the context of the postmodern pluralist world - that also attempting to explore the historical origins of school-centered education science. The school system of absolute monarchies sought exclusive legitimacy, and ordered that legitimacy from science.

Kulcsszavak: neveléstudomány, iskola, extrakurrikuláris aktivitások, tanulási folyamat

Keywords: educational sciences, school, extracurricular activities, learning process

A Magyar Tudomány idei első száma (2020/1) arról értesíti a „magyar tudományt", hogy a neveléstudomány narratíváiban, tárgykörében csak és csakis az iskoláról (megengedően akár: egy jó iskoláról) esik szó. Jó iskola, hiszen van benne „nonkognitív” fejlesztés is, de mindez az osztályterem, a tornaterem, a díszterem és a tanári szoba szürke - vagy éppen tarkára meszelt - falai között, történik. Bár itt is csak a falak színéről és állagáról beszél, arról, hogy ténylegesen mi folyik a falak között, kevéssé. Nem szól az áttekintő szám a rejtőzkö- 
dő tantervröl, azaz, hogy a történelem, magyar, matematika tantárgyak tanítása mellett milyen tanulási folyamatok zajlanak valójában a tanulók világában, sem a tanulást, testi/lelki gyarapodást és jóllétet elősegítő vagy akadályozó, hovatovább megbetegítő, az intézményekben kialakuló malignus folyamatokról. Nem beszél a tanórán túli, de az iskola szervezte tevékenységekről, amelyek legalább annyira fontosak, mint a tantárgyakba rejtett tudás. Végül meg sem emlékezik azokról a nevelési konstruktumokról, helyzetekről, folyamatokról, amelyek nem az iskola falai között zajlanak. Ebben a vitairatban kísérletet teszünk a szakmánkban terjedő „oktatástudomány” helyett a „neveléstudomány” kifejezés rehabilitációjára, olyan értelmezésre, amelyben valóban tudományos érvényű reflexió tárgya lehet az a jelenségvilág, amelyet 'nevelésnek' nevezünk.

Miért félnek modern teoretikusaink a 'nevelés' kifejezés használatától? Kétségtelen, hogy a nevelés kifejezést annyira megterhelték a különböző - jobbára totalitárius - ideológiák szólamfogalmazói, hogy (főként a posztszocialista országokban szocializálódott szerzők) egyszerüen tartanak a használatától. De ki mondta, hogy a fentebb emlegetett „pedagógiai ideológusok” nem csupán magukat, hanem az egész tudományt kompromittálták? ${ }^{1}$

Az „önmagát megteremtő” ember empirikus valósága és szakmánkban egyre inkább visszatükröződő ideája további tudományos megerősítést kapott a személyiség-lélektani elméletek különböző eredményeitől. ${ }^{2}$ Felértékelődik a helyzet és a személy kölcsönhatása, amire tulajdonképpen a szociális-kognitív tanuláselmélet építkezik (környezet, viselkedés és a személyiségtényezők interakciója). A konstruktivizmus igazolja, hogy minden tanulás és minden személyiségbeli változás megjárja a „tudat ösvényeit”. Ez a tudományos tapasztalat a tanítás helyébe is a tanulást, illetve - didaktika gyanánt - a tanulás támogatását és a tanulási környezet megteremtését illesztette fogalmilag, hát akkor ez miért is ne igazolná, hogy a science of education a tanulás tudománya legyen? ${ }^{3}$

${ }^{1}$ Érthető ez a menekülés, ha a neveléstudós a híres makarenkói mủ címének egykori - egyébként árulkodóan túlbuzgó - magyar fordításának metaforájára gondolva a személyiségfejlesztés ideáját a kovácspöröly alatti átformálásként értelmezi.

${ }^{2}$ Ma már túlhaladott a behaviorizmus, amely szerint csak a megfigyelhető viselkedés („csak a tanár szeme előtt folyó oktatás”) tanulmányozható, s a belső mentális folyamatok és változók a funkcionális elemzés számára irrelevánsak.

${ }^{3}$ Történt kísérlet a diszciplína elnevezésének kompromisszumos változtatására is. A két fogalom közti „különbségtétel inkább a makro- és mikro-szintű orientáció megkülönböztetéséről vagy az interdiszciplinaritás mértékéről szól, és nincs köze ahhoz az igen elterjedt, a neveléstudomány legtöbb hazai képviselöje által osztott és a hazai oktatási jog által is megerősített szóhasználattal, amely az »oktatás« alatt szűken a tanítást érti és azt a »neveléssel« mint tágabb, az előbbit magába foglaló fogalommal állítja szembe. Érdemes tehát hangsúlyozni: ....az oktatás általános átfogó fogalom, amely megfelel az angol »education« fogalmának, magába foglalva egyfelől mind a makro (vagy rendszerszintü), mind a mikro (vagy osztálytermi és egyéni) szintű jelenségeket, másfelől mind a tanítás/tanulás, mind a nevelés vagy szocializáció jelenségvilágát.” (Halász, 2013, 3.). 
A neveléskutatás oktatástudománnyá torzulásának másik oka az, hogy az ember megsegítésének hatékonysága e területeken látszik a leginkább jól mérhetőnek. És míg egyetérthetünk azzal a kijelentéssel, hogy ami „nem mérhető, az nincs is", ez nem jelenti azt, hogy mindent tudunk mérni, ${ }^{4}$ vagy minden esetben érdemes mérni. ${ }^{5}$

Tény az is, hogy a modern pedagógia tudománya alapvetően egyetemi dolgozó- és könyvtárszobákban „,nőtt fel”, a nagy 19. századi elméletek a „tanárképzés szolgálatába" állított tankönyvek voltak valójában (Németh, 2013). Persze, hogy a nevelési folyamatban betöltött szerepek közül a „tanári” (eleinte tanférfiúi) és a tőle függő „diák” szerepei artikulálódtak ezen opuszokban, ${ }^{6}$ ahogyan ezt a 19. század végére kialakuló modern tömegiskola világa ezt elképzelte és megkövetelte. Ám az iskola ezen ,szép új világa”-keretezte tudományosságban arról sokszor hajlamosak vagyunk megfeledkezni, hogy az „iskolán kívül” is van élet: s nem csupán spontán szocializáció van - így például családban, munkahelyen, de akár a honvédségben, egyházaknál, civil szervezeteknél ${ }^{7}$-, és megannyi intézmény, szerveződés, társadalmi alrendszer kapott társadalmi felhatalmazást arra, hogy az új nemzedékekre (s egyre inkább a Lifelong Learning - az életen át tartó tanulás - elve és gyakorlata jegyében: egész életutakra) fejlesztő befolyással legyen. ${ }^{8}$ A példák mind-mind arról szólnak, hogy az iskola helyett, később akár mellett

\footnotetext{
${ }^{4}$ Vö.: Newton „almája” és a LIGO projekt 330 évnyi különbségét.

${ }^{5}$ A szemhéjak elhelyezkedésére és annak időbeli változására különösen szép egyenletek és szoftverek dolgozhatóak ki, míg egy pedagógus felismeri növendéke fáradtságát.

${ }^{6}$ Mindazonáltal az 'education' kifejezés az angolszászoknál valóban az emberi fejlődés segítésének minden oldalára érthető. A német hagyományban ott az „Erziehung” és a „Bildung” különbsége, az orosz (szovjet) tradícióban, nyelvhasználatban a „voszpitanije” és az „ucsénije”. $\mathrm{S}$ furcsa grimasza a sorsnak, hogy éppen e két nyelven születtek azok a borzasztó ideák és ideológiák, amelyek tudományként takarták el a személyiség fejlődésébe való erőszakos beavatkozás hatalmi szándékait!

${ }^{7}$ Melyekről egyebek mellett a nevelésszociológia nevü, a neveléstudománytól elhatárolódó diszciplína szól (Kozma, 2001).

${ }^{8}$ Eszébe nem jutott az antikvitásról szóló neveléstörténetnek kezelni azt a helyzetet, hogy a drámaversenyek előtt a chorégosz (ma producernek mondanánk) az iskolákban castingolta a szatírjátékok ifjú táncos fiait, holott vélhetően ezen ifjak nevelésének ugyanolyan fontos eszköze volt (ahogyan a színházi élménynek volt andragógiai funkciója), mint a 16-18 évesek kötelező katonai szolgálata, az ephebeia. Kevés szó esett arról, hogy a templomok kórusaiban oly áhítattal éneklő vagy éppen a passiójátékokon „rendetlenkedő” (Demeter et al., 2009) vagy más egyházi szolgálatot teljesítő gyerekembereknek mennyire szolgálta a „vallásos nevelésüket”, egyéb emberi habitusukat mindez. A piacok terein fellépő „csepürágók” és „képmutogatók” fontos szerepet töltöttek be a gyerek- és ifjúvilágban, a tollfosztók, tengerihántók, fonók pedagógiai jelentőségéről, ha más nem, népmeséink és népballadáink tanúskodnak. Folytathatnánk a sort a falusi-paraszti társadalom hagyományainak és szokásainak oly gazdag rendszerével, mely sokáig felért megannyi iskolai leckével (Gazda, 1980; Kresz, 1949; Kiss, 1939; Sándor, 2019).
} 
valóságos és funkcionális alrendszerek szolgálták az új generációk „belenevelődését" a társadalomba.

Fontos szempont, hogy a népiskolát, tömegiskolát a felvilágosult abszolutista birodalmak teremtették, amelyeknek volt okuk arra, hogy elpusztítsanak - teoretikusan is - mindent, amit nem ők ellenőriznek. ${ }^{9}$ Az iskola kialakulásához kapcsolódó tudományos neveléstant már ezek a nagyon is határozott személyiségformáló célokkal - például alattvalói-állampolgári hüség stb. - színpadra lépő iskolateremtő államok rendelték. ${ }^{10}$ Ezt az optikai csalódást (csalást?) nem igazán vette észre a születő modern neveléstudomány - így fogant, és így maradt az iskolapedagógia fogságában. Így esett, hogy minden, ami ezen kívül maradt, kívül esett a hivatalos „oktatástudomány” világán. E tendenciát a gyermektanulmány (pedológia) - amely azzal a szándékkal született meg, hogy a hatalom szükös megbízásai, felhatalmazásai, nevelésképe helyett a növendék, a gyermek helyzetét tanulmányozza - rövid epizódja törte csak meg, ${ }^{11}$ pedig közben Európa-szerte kibontakoztak a „nevelés” világához sorolható jelenségek, így a serdülömozgalmak, a gyermekkultúra világa. ${ }^{12} \mathrm{~S}$ ez így ment - az iskola alapvető, ontologikus létformájának elfogadtatott comeniusi-herbarti-jezsuita tradicionális iskola diadalútjával ${ }^{13}$ - a múlt század hatvanas éveiig, amikor is az iskolaintézmény általános válsága több narratívában is felködlött.

Ma már azonban Ivan Illich (1970) és John Holt (1969), és az iskolátlanítás más teoretikusai nélkül nem lehet neveléstudományról beszélni - hazánkban sem. Adódott az egyik válasz: a tudományterület célja legyen a tanítás technológiáinak a tökéletesítése, a tudásipar kialakítása (Radó, 2017; Mihály, 1998). De adódik, kell hogy adódjon egy másik is: egy új iskolafunkció leírása, visszatük-

${ }^{9}$ Ezt a szándékot általában az alternatív tudásközvetítő helyekkel szembeni fellépés jellemzi, legyen erre példa az alföldi „zugiskolák” üldözése (Dedinszky, 1977; Iván, 1976), az 50-es években rejtőzködő „katakombacserkészet” elfojtása (Kamarás, 1994, Aczél, 2005), de még a civil szerveződésként létrehozott úttörömozgalmat is visszapréselték 1949-ben az iskola világába (Trencsényi, 1987). Jellemzően, egy adott hatalom konszolidációja során a berendezkedést legitimálandó rendszeresen fellép a nem általa diktált tudás- és értékosztó színterek ellen. A „regösök csacska beszédét” elítélő Anonymus is egy ilyen „pedagógiai kultúraváltás” szószólója volt (Karancz, 1997).

${ }^{10}$ A szükséges elemi tudáson túl Mária Teréziának németnyelv-tudás és polgári ismeretek, Nagy Frigyesnek a tüzérség számára oly szükséges matematika, Nagy Katalinnak a csaknem vad szibériai törzsek civilizálása volt fontos stb.

${ }^{11}$ Nem véletlenül lett a gyermektanulmány a reformpedagógiai teóriák egyik forrása. A pedológia keményen kerékbe töretett, éppenséggel a totális államok (melyek önfeledten rekonstruálták a tradicionális iskolát) dúlták szét (Mihály, 1998).

12 A gyermekvédelem, gyerekszínház, mozi, gyereksajtó, túramozgalmak, táborozások stb., hát persze, hogy tudományos elemzésért kiáltottak (Deák, 2000; Nógrádi, 1913; Nógrádi, 1917; Korczak, 2019).

${ }^{13}$ Évfolyam, osztály, a tudomány aktuális rendszertanát mindig késéssel követő tantárgyi rendszer, tanóra, tanterv, osztályozás, „,nevelőoktatás”, azaz a több tudással lesz több erény elve. 
rözése, amely számol a „felnőtt társadalom” felelősségével, megőrzi-fejleszti a tudástranszfer profizmusát, de számol azzal is, hogy a gyerekeknek egyszerüen „hely” kell, ahol biztonságban tudják őket szüleik, ahol - bizonyos védelem mellett - megteremthetik, ,saját világukat”.

Csapó Benő bevezető tanulmányában science denialt (elutasított tudományt) emleget, mint a politika szemellenzőjét, vakfoltját, ha nem figyel a tudomány biztos eredményeire. A fent leírt jelenségvilágból azonban ő is csupán annyit lát a „neveléstudomány releváns témaköreinek” számbavétele során, hogy „,vizsgálat bizonyítja a nemkognitív tulajdonságok meghatározó szerepét az iskolai tanulásban" (Csapó, 2020, 9.).

Meg kell értsük, hogy az iskola nem egyetlen és még csak sokszor nem is kiemelt helyszíne a tanulás folyamatának. Kudarcként élheti meg ezt sok nagy oktatásmódszertani elmélet kutatója, mérő és értékelő szakember, a didaktikai alapelveket tételszerủen számon kérő oktató, de a médiatér, a kortárscsoportok eltérő tanulási terének utóbbi időben való robbanásszerű megerősödése, ha nem is teszi zárójelbe az iskolát, de visszahelyezi az „egyetlen” piedesztáljáról az „egyik” sorába.

De még a fegyelmezett és fegyelmező célracionalitás, a nevelés szempontjából is önellentmondásos, hogy ez kizárólag egy olyan épületbe zárt folyamatban érvényesülhetne, amelynek falára legalább az ISKOLA hat betüje ki van írva. Napjaink társadalmára kifejezetten az a jellemző, hogy újabb és újabb állami és civil, egyházi és piaci alrendszerek jelennek meg legitim nevelési színtérként. A plurális nevelési térképen ezek a „,helyek” - különösen, mert a szolgáltatások igénybevevőinek önkéntes választására épülnek - nemegyszer hatékonyabbak a maguk nevelési-fejlesztési feladataik teljesítésében, mint a hatalmi viszonyokkal megterhelt iskola. A nyelviskola, gépjármüvezetői tanfolyam, színház, ifjúsági szórakozóhely, tábor, klub, mozgalom, egyházi közösség, virtuális csoport stb. sok szempontból akár eredményesebben szolgálhatja az önfejlesztést vagy a társadalmi célokat. Ezen új világok neveléstudományi metodológiával, neveléstudományi narratívában végbevitt elemzésekért kiáltanak. Nem mint az iskola „kiegészítői”, hanem mint megannyi sajátszerüséggel rendelkező pedagógiai entitások.

Mindezzel a neves szegedi vendégszerkesztő még csak érintőlegesen sem foglalkozott, pedig a terület mégiscsak így értelmezhető a tudományos összhangzatban. És ezért mégiscsak javasoljuk: nevezzük ezt az egész tudományos narratívát - neveléstudománynak. 


\section{IRODALOM}

Aczél L. Zs. (2005): Parázs a hamu alatt. Budapest: Új Ember-Márton Áron Kiadó

Csapó B. (2020): Bevezetés: neveléstudományi kutatás és a tudományos eredmények alkalmazása. Magyar Tudomány, 181, 1, https://mersz.hu/hivatkozas/matud_319

Deák G. (2000): A magyar gyermektanulmányi mozgalom története I. Budapest: Magyar Pedagógiai Társaság-Fővárosi Pedagógiai Intézet-OPKM

Dedinszky Gy. (1977): Az úgynevezett „zugiskolák” Békéscsaba tanyavilágában. Békési Élet, 12, 4, 496-505. https://library.hungaricana.hu/hu/view/BekesiElet_1977/?pg=509\&layout=s

Demeter J. - Kilián I. -Pintér M. Zs. (szerk.) (2009): Ferences iskoladrámák I. Csíksomlyói passiójátékok 1721-1739. Budapest: Argumentum-Akadémiai Kiadó

Gazda K. (1980): Gyermekvilág Esztelneken. Bukarest: Kriterion Könyvkiadó, http://adatbank. transindex.ro/html/cim_pdf1002.pdf

Halász G. (2013): Az oktatáskutatás globális trendjei. Budapest: ELTE Eötvös Kiadó http://nevelestudomany.elte.hu/downloads/2013/nevelestudomany_2013_1_64-90.pdf

Holt, J. (1969): The Underachieving School. New York: Delta Book

Illich, I. (1970): Deschooling Society. New York: Harper \& Row

Iván L. (1976): Zugtanítók, zugiskolák. Köznevelés, december 24.

Kamarás I. (1994): Bensőséges bázisok. Budapest: OKI, https://mek.oszk.hu/14000/14044/

Karancz G. (1997): „Pedagógusok” az ún. Kassai Kódexben. Iskolakultúra, 1, 29-31. http://real-j. mtak.hu/10010/1/EPA00011_iskolakultura_1997-1.pdf

Kiss L. (1939): A kiskondás. In: Kiss L.: A szegény ember élete. Budapest: Athenaeum

Korczak, J. (2019): A wilhelmówkai fiúk. (ford. Pászt P.) Budapest: Magyar Pedagógiai Társaság

Kozma T. (2001): Bevezetés a nevelésszociológiába. Budapest: Tankönyvkiadó, https://dea. lib.unideb.hu/dea/bitstream/handle/2437/163174/t_dekdb_bibDRT235627.pdf;jsessionid=7D38A5907DE44D81AF6879BF1F733BF1?sequence=3

Kresz M. (1949): A hagyományokba való belenevelődés egy parasztfaluban. In: Ortutay Gy. (szerk.): Néprajzi Tanulmányok 1. Budapest: Pázmány Péter Tudományegyetem, https:// en.mandadb.hu/tetel/427191/Kresz_Maria_A_hagyomanyokba_valo_belenevelodes_egy_ parasztfaluban_cimu_munkaja

Mihály O. (1993): A neveléstudomány helyzete. Új Pedagógiai Szemle, 4.

Mihály O. (1998): Bevezetés a nevelésfilozófiába. Budapest: OKKER

Németh A. (2013): A neveléstudomány főbb fejlődésmodelljei és tudományos irányzatai. Neveléstudomány, 1, http://real.mtak.hu/37990/1/nevelestudomany_2013_1_18_63_u.pdf

Nógrádi L. (1913): A gyermek és a játék. (Gyermektanulmányi Könyvtár 1. kötet) Budapest: Magyar Gyermektanulmányi Társaság

Nógrádi L. (1917): A mese. (Gyermektanulmányi Könyvtár, 7. kötet) Budapest: Magyar Gyermektanulmányi Társaság

Radó P. (2017): Az iskola jövője. Budapest: Noran Libro Kiadó

Sándor I. (2019): Ethnopedagogy: The Term and Content. Acta Generalis Pedagogiae, 3, DOI: 10.2478/atd-2019-0016, https://www.researchgate.net/publication/338109432_Ethnopedagogy_The_Term_and_Content

Trencsényi L. (1987): Az úttörő szorgalmasan tanul, de nem osztja meg másokkal a tudását. Ifjúsági Szemle, 1. 